\title{
Developing Team Skills in Accounting Students: A Complete Curriculum
}

\author{
Alexander Z. King \\ Saint Xavier University \\ Harold King \\ NYPIT LLC
}

\begin{abstract}
Employers continue to demand increased levels of team and interpersonal skills in graduating accountants. Scholarly and professional works continue to reinforce this demand. Despite this, there remains a dearth of resources available to universities to integrate team skills education into accounting curriculum. This paper directly addresses this issue by providing a specific teamwork curriculum for implementation in accounting programs. In this paper, we detail the team skills required of accounting graduates, provide implementation recommendations, supply a complete set of curriculum resources, and provide assessment templates. This paper reduces the barrier for universities to implement team-skills content within their accounting programs.
\end{abstract}

Keywords: teamwork, team skills, accounting curriculum accountant soft skills, AACSB accreditation, interpersonal skills

\section{INTRODUCTION}

For more than 20 years, all types of businesses have demanded improved team skills in graduating accounting students. As indicated by a wide range of contemporary work (see, for example, Casper, 2017; Marasi, 2019; and Tannenbaum \& Salas, 2021), this demand continues to exist today. While some Universities have added 'group-work' exercises to their teaching repertoire, in most cases they have not provided team knowledge and skill building resources and curriculum that is well-researched, thoroughly developed, and which is consistent with business and industry team practices. Merely breaking a class into small sub-groups and assigning them to work "as a team" does not satisfy the demanded requirements of their future employers.

This paper and it's attached education process were developed in response to employer demands for increased levels of teamwork skills in business graduates, as well as in response to the AACSB (2020) requirements for, "Continuous improvement in business school curriculum, and relevance in work-related course content". While strongly referenced, and based on the extensive team development work of the authors (the authors have trained more than 3,000 people in teamwork), this paper's focus on delivering team skills education to university accounting curricula is original work.

The objectives of this paper are to: 
- Summarize the demand for increased team skills in graduating accountants, as specified by business, public accounting firms, educators, and accounting professional societies.

- Define a curriculum to meet these demands.

- Fit that curriculum into the schedules of existing accounting courses. We provide a twomodule structure to be inserted across two separate accounting courses. Each module is intended to take two to three hours.

- Provide (via Appendix A) all of the material necessary to teach these two modules, including: PowerPoint slides, reference data, exercises, class discussions, assignments, rating materials, professional application materials, and experience tracking methods. All of this is tailorable by the user.

- Provide evaluation methods for both quantitative and qualitative effectiveness of the education and process.

While the subject of teamwork has many facets, we have sorted out the critical few topics of primary importance in developing basic team skills and focused them toward accounting education. In order to make the paper easy to follow, we will utilize numerous sub-headings and summary lists - with additional detail available in the course materials presented in the appendices.

This paper is appropriate for the following audiences:

- University and college accounting educators - as a directly applicable teaching resource. It is equally applicable to United States and International accounting educators.

- Individual accounting students - as a self-study resource for developing teamwork knowledge.

- With minor adaptation to the existing accounting related language and cases, this paper and the Appendix A course materials can be applied to other collegiate disciplines and to business practitioners.

This paper aligns with the requirements and recommendations of the following professional organizations:

- AICPA Business Competencies: Process and research management.

- AICPA Professional Competencies: Collaboration, Leadership, Communication, Project management.

- AACSB 2020 Business Standards. Standard 4 - Curriculum:

○ 4.1: "The school delivers content that is current, relevant, forward-looking, globallyoriented."

- 4.3: "The school's curriculum promotes and fosters innovation, experiential learning, and a lifelong learning mindset."

- 4.4: "The school's curriculum facilitates meaningful learner-to-learner and learner-tofaculty academic and professional engagement."

- Pathways Commission:

- Objective 4.2: "Implement curricular models of the future."

- Objective 5.1: "Enhance perceptions of the study of accounting and career opportunities in accounting."

- Objective 5.2: "Transform the first course in accounting."

As a contribution to the literature, this paper provides a unique set of teamwork principles, concepts, methods, learning outcomes, and teaching materials to the accounting education profession, and makes them fully available for use. This is turn allows universities and colleges to introduce a long-demanded teamwork education to accounting students, thus enhancing their preparedness for future employment.

This paper proceeds by documenting the demand for team skills in accounting graduates in Section II. Section III discusses how to meet the demands for team skills in accounting students. Sections IV and V detail the team skills curriculum model and related assessment of learning, respectively. Section VI addresses the logistics of implementing the curriculum in an undergraduate accounting program and Section VII concludes. Appendices A through C contain the teaching resources for Modules I and II, and related learning assessment tools. 


\section{THE DEMAND FOR TEAM SKILLS IN ACCOUNTING GRADUATES}

\section{Demand From Employers}

Over the past 25 years, researchers have documented employers' demands for accounting graduates to demonstrate increased abilities in working on teams (Casper, 2017). Yet this demand has not been satisfied. Hughes and Jones (2011) cite a 2009 poll by the Association of American Colleges and Universities (AACU), in which 71 percent of employers indicated a need for increased teamwork and interpersonal skills in graduates. Similar arguments have been made by Ballantine and Larres (2009); Daff, de Lange and Jackling (2012); Maali (2020); and Marasi (2019). Argarwal, et al., (2018) point out that a network of teams is common in business today, yet our accounting education has not filled the demand for team skills.

The Center for Creative Leadership (Martin \& Bal, 2006), found that $91 \%$ of respondents indicated that teams were a vital foundation of their organizations' success. Hobson, et al., (2014) lists more than a dozen studies indicating teamwork as a vital skill. In defining employer expectations, Marasi (2019) has examined the Job Outlook 2017 by the National Association of Colleges and Employers. In her analysis, she reveals that $78 \%$ of survey respondents listed teamwork as the top non-technical skill that is required in graduating students. Interpersonal skills, also developed within teamwork processes, were listed with a $70 \%$ demand (also see Christensen, et al., 2019; and Tan \& Laswad, 2018).

Employers in a great variety of businesses, both in the USA and internationally, require teamwork skills in their accounting new hires. Hughes and Jones (2011) cite a 2009 poll by the Association of American Colleges and Universities (AACU), in which 71 percent of employers indicated a need for increased teamwork and interpersonal skills in graduates (also see Albrecht \& Sack, 2000; Bryant \& Albring, 2006; Howieson, 2003; Jackling \& De Lange, 2009; Jones, 2014; McGuigan \& Kern, 2016; Paguio \& Jackling, 2016; Rainsbury, et al., 2001; and Tannenbaum \& Salas, 2021). According to their research, well-trained accountants with a proven base of team skills will receive the best job offers, and universities which develop these skills will gain the preferred reputations for contemporary skill development.

In practical business use, Six Sigma is the most utilized formal business improvement process in application today. Teams are formed within Six Sigma projects to study and improve business processes. These teams almost always include an accountant to manage the data needs and financial tracking for the project team. Six Sigma experts Arumugan, Antony and Kumar (2013, p.394) note, "Teams are the fundamental learning units in organizations. Team learning is a process in which a team takes action, obtains and reflects on feedback (and data), and makes changes to adapt and improve." They list the work of 779 work teams, across a variety of industries and work locations, which were employed to achieve improved results in project management between 1999 and 2007.

\section{Demand From Educators}

Lawson, et al., (2014) explain that the development of foundational team skills must be accomplished within our core accounting curriculum, and not as a remote outlier. In their paper regarding competency integration into accounting education, Lawson, et al., (2014) present a framework which integrates the learning of foundational competencies into accounting competencies. These foundational competencies (outlined in Figure 1, below) include the ability to work together in teams in order to solve problems and make decisions. Team skills are related to those accounting competencies outlined in red. 


\section{FIGURE 1 \\ COMPETENCY INTEGRATION MODEL}

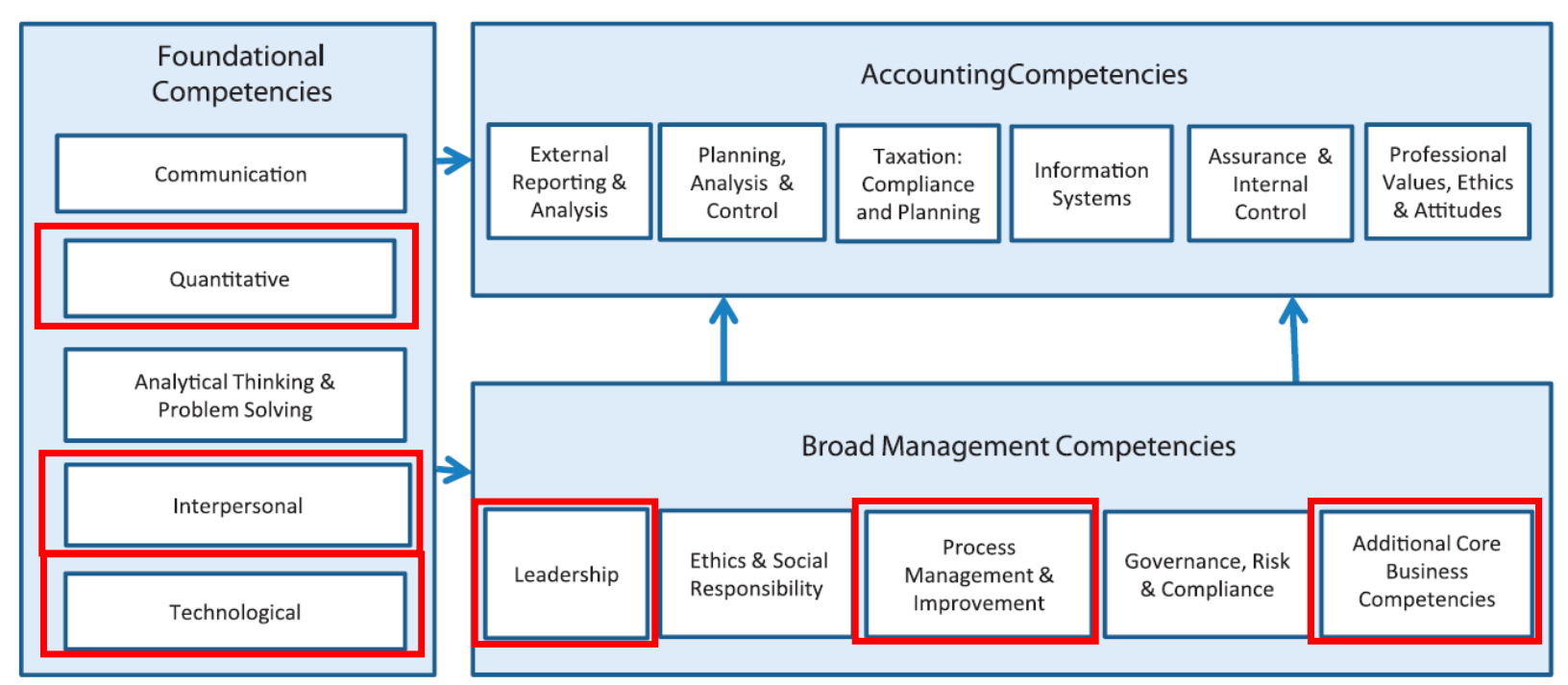

Lawson, et al., 2014

Hughes and Jones (2011) cite a 2008 College Board study which lists teamwork and collaboration second on a list of predictors for job success. The research report by Rainsbury, et al., (2001) surveys courses and requirements in education from 253 undergraduate students and 35 graduates. Their findings place teamwork as the number two non-technical skill required by business students, behind interpersonal skills (also see Driskell, 2006; Chaffer, 2017; Gammie, et al., 2002; Tonge \& Willett, 2009; Kennedy \& Dull, 2008; and Schmulian \& Coetzee, 2019).

Marasi $(2019$, p.324) cites a dozen references who indicate that, "Faculty can enhance student learning about teams by providing a realistic preparation, an understanding of the team development process and team member interactions or team dynamics, and an appropriate development of teamwork skills."

Opdecam and Everaert (2012) provide strong support for the need for team learning, but stop short of developing how to bring about team learning. Birrell (2006); Jones and Abraham (2008); Kavanagh, et al., (2009); and Swain and Olsen (2012) indicate that teamwork skills are an imperative if accounting graduates are to obtain valued positions in the enterprise of tomorrow. Riley, et al., (2013, p.805) provide optimism for well-skilled accountants, noting, "With experience, accountants have a competitive advantage over many business professionals because they embrace numbers and develop solutions to difficult problems."

Despite the excellent research into team skills requirements within graduating accountants, we have seen little in the extant literature which defines a specific curriculum, and provides related content resources for providing a high-quality teaching resource for accounting educators and students. That is the purpose of this paper.

\section{Demand From Professional Societies}

Bryant and Albring (2006) indicate that a prime driver for team building education is the accounting profession itself. They cite publications and certification exams from the Financial Executives Institute, The Institute of Internal Auditors, and the American Institute of Certified Public Accountants - all defining the need for team building skills via employer surveys, definition of professional standards, and core competency frameworks.

The CPA Vision 2011 Project, sponsored by the AICPA as well as the Pathways Commission Report (Behn, et al., 2012; Black, 2012) included numerous foundational skills as core competencies of successful accountants; among these were facilitation and teamwork. 
The AACSB does not define specific individual skills in their accreditation standards, preferring instead to mandate inclusion of broader topical areas. In concurrence with their methodology, we note that this paper supports their topical areas of continuous improvement, diversity, inclusion, relevance, globalorientation, and currency in curriculum. Team methodology also fulfills dictates of, "Encourages students to take responsibility for their learning" (AACSB,2020, p.40) and, "Competencies that prepare graduates for business careers" (AACSB, 2020, p.38). The teamwork competencies inclusive to this paper, and its attachments, are clearly in support of this AACSB curriculum.

\section{Demand for Teamwork Skills - Internationally}

We all participate in a world market, and many of the skills sets and accounting standards which are applicable in the United States are equally applicable to international business, educational and governmental entities. Additionally, many of us encounter international students in our universities, and international business representatives in our research and our practitioner work, so a common language of teams is desirable and will ease students' bridge from their education to their early careers.

Internationally, we find the demand for teamwork skills in accountants to be fairly universal, with researchers demonstrating the need for team skills in Australia (Howieson, 2003; Kavanaugh \& Drennan, 2007; and Wilcoxson, 2016); New Zealand (Gray, 2010; Wells, et al., 2009); Tunisia (Klibi \& Oussii, 2013); Indonesia (Sumaryati, et al., 2020); Jordan (Bassam \& Al-Attar, 2020); Canada (Leroux \& Lafleur, 1995); Saudi Arabia (Zureigat, 2015); Nepal (Dahal, 2019); and the United Kingdom (Van der Stede, 2018; and Zraa, Kavanaugh, \& Hartle, 2011).

\section{Applicability to Other Educational Disciplines}

It is a key responsibility of this study to point out that if other university disciplines are developing teamwork skills and university accounting departments are not, this not only reflects poorly upon the accounting department, the business school, and the university, but also on our accounting graduates, who enter the workforce with an incomplete set of skills. If our accounting graduates are not sufficiently trained, they could be replaced with higher skilled graduates with a broader set of teamwork and other applicable skills.

Fields outside of accounting which are requiring teamwork skills include engineering (Arumugam, et al., 2013; Chowdhury \& Murzi, 2019; Lingard, 2010; Smith, 1995; and Smith, 2015); computer science (Lingard, 2010); sales (Tannenbaum \& Salas, 2021); healthcare (Loughry, Ohland \& Woehr, 2014; and Xyrichis \& Ream, 2007); manufacturing (Scholtes et al., 2018); design (Tucker \& Abbasi, 2016); and for leadership in general (Bloch, et al., 2012).

\section{SATISFYING THE DEMAND}

\section{Groups vs. Teams}

Many accounting faculties already incorporate group work and projects into their courses. As currently implemented, though, much of this 'group work' is inadequate to prepare students for employer requirements of team skills upon entering the workforce. In lieu of delivering a comprehensive program to educate students on team skills and proceeding to have students practice these skills in their group work, many faculties assign ad hoc groups, assuming the mere existence of group assignments prepares students well for their careers.

However, well-functioning teams have defined processes and methods to define objectives, improve processes, get the work done, measure results and summarize and present their findings. 'Groups' are generally more temporary, and more loosely conducted. The standard practice in too many accounting courses is to assign students to work in groups, without proper preparation to work in teams.

Employers demand a knowledge set of how teams are organized, and how they function to achieve meaningful results and solve difficulties as they arise. "There is a science to a well-functioning team effort, and this science has largely been ignored" (Tannenbaum \& Salas, 2021, p.5). We thus proceed with 
information and practices that are well-tested and commonly used in teamwork throughout business, industry, education, and government applications.

\section{Selecting the Knowledge and Skills to Be Developed}

Tannenbaum and Salas, in their recently published Teams That Work (2021), define the following capabilities (knowledge, skills and abilities-KSA's) as necessary within a team and its members:

- Communication skills

- Feedback skills

- Conflict prevention and management skills

- Interpersonal skills

- Leadership skills

- Teamwork savvy and practices

Tannenbaum and Salas (2021) utilize this framework for describing team skills, and importantly, as a framework for evaluating team member skills. They do an excellent job at differentiating these skills at a level far above the typical formation of a temporary work group and indicate that these skills are not typically sufficiently developed within a traditional academic curriculum.

Purdue University received grants from the National Science Foundation for \$4.2 million to develop a process and support system for the selection and peer-evaluation of team members during project work and upon project completion. Titled CATME (Comprehensive Assessment of Team Member Effectiveness; Ohland et al., 2014), this model defines teamwork across five dimensions:

- Contributing to the team's work

- Interacting with teammates

- Keeping the team on track

- Expecting quality

- Having relevant knowledge, skills and abilities (KSA's)

These dimensions are further defined by a table of 34 potential team knowledge sets, skills and behaviors, tailorable to the user's needs (while there are 34 skills, CATME recommends only 16 in their primary rating instrument). Students using the CATME tool use a five-point Likert scale to self-rate and are also rated by their peers along the teamwork dimensions. The software then provides reports on the differences between self and peer evaluations and identifies areas where instructors may wish to intervene.

We consider CATME to be an excellent tool, and we recommend it for its intended purpose of team formation and team peer evaluation. However, CATME provides very little in teamwork education, outside of a few one-minute videos regarding how to utilize their system.

When determining how to deliver and assess team skills to our students, we must remember that we are teaching recent high school graduates of varying talents and competencies, many of whom have no background in the use of business-related team skills. To move directly into team projects as freshmen and sophomores, and then on to peer evaluation (such as with CATME) - without providing the requisite education and skill development - is a big jump, and does little but set students up for poor performance.

Instead of adopting wholesale the Tannenbaum and Salas (2021), CATME, or other published definition of required team skills required for accounting undergraduates, we create our own definition of required team skills. We utilize the team skill definitions from Tannenbaum and Salas (2021) and CATME as a foundation and tailor them to meet the needs of accounting undergraduates. Selected skills must be appropriate for recent high school graduates with little to no knowledge of team work, or with few skills yet developed. Further, these skills must be applicable throughout the business school, but also tailorable to any specific academic department. We have done such tailoring to achieve accounting curriculum learning objectives described within employer demands, AICPA competencies, Pathways Commission, and the AACSB. In selecting our skills, we find that they incorporate the selected skills of both the CATME categorization as well as the Tannenbaum and Sales (2021) selections, with strong reference to the work of Nash, et al., (2005) and Scholtes, et al., (2018), and our own work training more than 3,000 adults in 
business, government, and education. We have identified 23 team skills required by accounting students. They are described in the next section.

\section{Team Definition and Knowledge and Skill Development Listing}

Following the lead of one of the most respected authors on team development, we will utilize the definition of a team from Scholtes, Joiner and Streibel (2018, p.A-4), in their landmark bestselling The Team Handbook. They define a team as, “... a group of people working together to achieve a common purpose for which they hold themselves accountable."

They list the key elements as:

- $\quad$ The members have a shared work product

- Tasks are interdependent; the work could not be accomplished by people working independently

- There is a shared responsibility for output and results

- There is a commitment to a common approach to working together

- Members collectively manage their relationships across organizational boundaries

Based on this team definition, and in review of our needs' analysis, as well as the knowledge and skill listings related to Tannenbaum and Salas (2021) and CATME (2020), above, the following 23 knowledge and skill learning outcomes have been selected as critical for student success as they begin their careers. You will note that the educational program is divided into two learning modules, one module to be presented within each of two accounting courses.

\section{Module One}

Background - Knowledge Building

1. Why develop team skills? Opening discussion with students

2. Role of the sponsor

3. Defining a team vs. a group

4. Types of teams, and their functions

5. Stages of team development

6. Roles and responsibilities for each team assignment

7. Skills required in each role

\section{Team Formation - Skill Development}

8. Forming the team and creating a team charter

9. Goal setting and action plans; identifying and creating team deliverables

10. Performance measurement

11. Setting a meeting agenda

12. Conducting an effective team meeting

13. Team project timing and measurement of progress and results

14. Adjourning the team

\section{Module Two}

\section{Team Process Improvement}

15. Process analysis and mapping

16. Process Improvement -The Deming Wheel of Continuous Improvement

17. Force field analysis

18. Overcoming team problems

Team Support Skills

19. Effective listening, reflecting and responding

20. Providing and receiving constructive feedback 
21. Ongoing role of the sponsor and mentor

22. Utilizing team skills in your post graduate life

23. How to be a star at teamwork

\section{TEAMS CURRICULUM FOR ACCOUNTING STUDENTS}

As noted above, the 23 learning outcomes are divided into two Modules. Module One is intended to be taught in a two-hour session in one of the freshman or sophomore-year required accounting courses. Module Two is designed to be included as a two-hour module in one of the junior-year required accounting courses. Further discussion of the logistics of implementing these modules is in Section VI.

In the following pages, we shall briefly describe the content of each of the 23 learning outcomes, and as necessary, provide additional content information to support the readers' understanding of the topic. The following explicit and detailed definition of a concise teams' curriculum for use in accounting undergraduate program is an advancement beyond what is currently in the literature. We expand upon this outline by providing teaching materials for each module and assessment tools for learning outcomes in Appendices A, B, and C. Appendix A contains:

- PowerPoint slides for each learning outcome; numbered in conformance to the topic list. As appropriate, tailored to accounting.

- Instructor notes, as required.

- Class questions and exercises.

- Suggestions for accounting related cases to be completed either in class, or more often, out of class.

While we address accountants as the target for this paper, other disciplines will find this information useful, and instructors can use the provided resources to tailor the teams' curriculum to the needs of their discipline and student demographics.

\section{Module One}

Module One contains the first fourteen instructional topics of the team skills curriculum. The focus of Module One is on the stages of team development, roles of team members, and how to behave effectively within team roles. Module One should be placed early in the accounting program to allow students to practice the knowledge gained and skills learned in the team assignments in other courses.

The teaching slides and teaching notes to accompany these topics are found in Appendix A. Such slides are numbered to be consistent with the twenty-three topics noted below.

\section{Opening Discussion With Students}

As we address the need for teamwork education to the faculty and students, it is necessary to explain the reasons, rationale, and methods for this addition to an already crowded accounting curriculum. This can be accomplished by explaining the 'Why' for the teams focus, and then we can proceed to the 'How,' the 'What,' the 'When,' and the 'Who.' We suggest that you utilize the slides in Appendix A, which address the following questions, with defined responses:

- Why are we focusing on teams in an accounting course?

- How will we develop this focus on teams?

- When will the team training start?

- In what courses will this training be included?

- What impact will the teams work have on student grades?

- Will grades be different for each team member, based on their contribution?

- How will we keep track of the teamwork learning process within our accounting courses? 


\section{Role of the Sponsor}

The team sponsor is the individual or group who empowers the team to invest the necessary time and resources to work on a project which is beneficial to the enterprise. In business terms, this would be a member of the management team, who has approval from their organization to divert employee time and allocate company resources to such an effort. In university settings, the sponsor would be the instructor or faculty member who is teaching the course, under approval of the content by the respective academic department and as described in the course syllabus.

The sponsor works with the team to define project goals, timetables, available resources, contact personnel, measures of success, tools available, format for project completion, and other mapping items for team success. An excellent method for the sponsor to convey the purpose and direction of the team is through use of the Team Charter, noted in item \#8, below.

\section{Defining a Team vs. a Group}

Peter Scholtes (Scholtes, et al., 2018) and his team at Joiner Associates have been a driving force in the use of teams to drive continuous improvement efforts for the past 30 years. Their Team Member Handbook and Team Leader Handbook are two of the most utilized published resources on teams. According to Scholtes, et al., (2018 p.1-2):

- A team is a group of people working together to achieve a common purpose for which they hold themselves accountable

- The members have a shared work product

- Tasks are interdependent; the work could not be accomplished by people working independently

- There is a shared responsibility for output and results

- There is a commitment to a common approach to working together

- Members collectively manage their relationships across organizational boundaries.

What a great definition! The definition discusses key factors of common purpose, accountability, shared work product, interdependence, shared responsibility, common approach, and self- management ... pretty much all one could want to see in a definition of teamwork! Because of this, we will use this definition of teamwork going forward.

\section{Types of Teams, and Their Functions}

There are at least six types of teams that are in common use (Nash, et al., 2005), and examples and applications for each are presented in this section. These examples are detailed within Appendix A. The types of teams are:

- Work management: the team takes responsibility for a segment of the work, such as quality inspection, and self manages that work.

- Process improvement: the team examines a work process that is not performing at desired levels, and determines how to improve the process. They then make the improvements and measure the results.

- Problem solving: something has gone wrong with a product or a process. The team is given responsibility for finding what is wrong, correcting it, and putting in place measures so that it does not occur again.

- Customer service: improvements in how the organization deals with customers are examined by the team, and measurable improvements are sought. The team determines the improvements, sets the targets, makes the improvements, and measures the results.

- Self-directed: the team takes on responsibility for managing most or all of their own work, to meet specific, defined performance levels. If there is a supervisor still involved, they take the role as mentor, and resource provider to the team.

- Direction setting: in this, a team may talk to customers, vendors, suppliers, management, and other workers to develop new product ideas, new production methods, and other new concept 
ideas which are different than those in use today. Frequently requires participation of a product manager, engineer, or a scientific expert to help explore possibilities.

There was a significant effort toward self-directed teams (Lee \& Edmondson, 2017; Renkema, et al., 2018) over the past 20 years, at such companies as Ford, General Motors, John Deere, Caterpillar, IBM and others. Following their trial projects, many of these companies determined that self-management was not optimal in their current work culture and that the continuation of a supervisory role was still necessary (Bergeil, et al., 2008; Gos, 2015; Langfred, 2007; and de Leede, et al., 1999). These companies determined that they were more comfortable establishing accountability for the work teams' output, and for coordination with management at an individual, rather than team level. The accountable person was usually the team supervisor. However, in most of these cases, team members still perform enhanced duties versus their historical, more narrowly defined job roles.

Some information technology jobs have a great deal of self-management (Hitt \& Brynjolfsson, 1997) and team management; this is facilitated by the ease of quantifying the quantity and quality of individuals' work output in the information technology setting.

\section{Stages of Team Development}

Bruce Tuckman (1965) was a psychological researcher who spent time in the 1960's observing various kinds of group work. He noted that all groups go through the same developmental stages, and that a group was unlikely to move to subsequent stages before they have satisfied the processes of the earlier stages. He published, Tuckman's Stages of Group Development in 1965, defining the first four stages. After continuing his studies, in 1977 he added the fifth stage, Adjournment (Tuckman \& Jensen ,1977).

While this model of team stages is five decades old, subsequent researchers failed to find a more easily digestible or widely applicable model. As such, we will use Tuckman's model for the stages of team development. Tuckman's team stages are defined as:

- Forming: members are selected and get to know each other. Initial team training.

- Storming: trust forms between team members; conflicts arise and are resolved.

- Norming: patterns are developed for smooth operations. Experts are invited to participate. Progress towards team goals is made.

- Performing: team continues to improve goal performance. The team establishes new levels and measures of performance, as they incorporate process changes into the workplace.

- Adjourning: added by Tuckman and Jensen (1977) to reflect the closure and follow-up activities to perfect the results of the team and celebrate their achievements.

FIGURE 2

\section{TUCKMAN'S FIVE STAGES OF TEAM DEVELOPMENT}

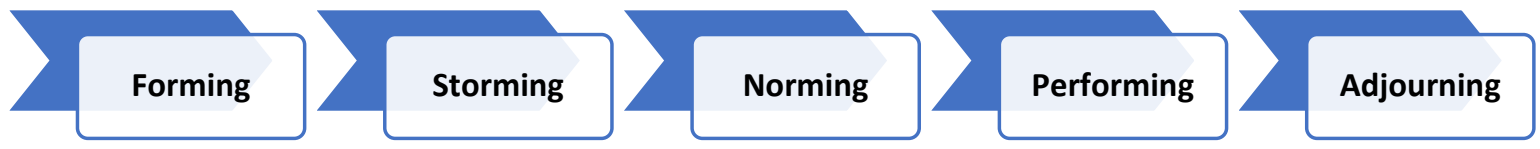

Teamwork skills are like any other skills; to get good at them requires practice, practice, and more practice. Through the use of sample exercises or case studies, and in the performance of accounting class work, teams are formed, roles are distributed, and the teams proceed with their assignments. Student teams will likely progress through all of the stages shown by Tuckman, and occasionally, someone will say, "Hey! We've slipped from performing back into storming" (or similar analogous comments). Once teams mature, they will find that they can move through the early stages of team development quickly and move onto the performing stage with little delay. 


\section{Roles and Responsibilities for Each Team Assignment}

In this section, each of the below listed roles (Nash, et al., 2005; Scholtes, et al., 2018) and duties are defined, examples are discussed, and samples are provided. A checklist is provided in Attachment A for each role, which the team member, the team leader, or the facilitator can use for individual performance feedback. A class discussion/quiz which matches team activities to team roles is also conducted to reinforce the learning outcomes. The team roles are:

- Leader: responsible for keeping the team organized and on track. Develops team agenda.

- Facilitator: keeps the team from wandering off target. Makes sure all team members ideas are heard. Helps Leader to resolve issues and conflicts.

- Recorder: keeps minutes and documents the team's progress. Charts team ideas.

- Member: brings up concepts and ideas, and assists in the research and work of the team.

- Sponsor: makes sure the team gets the resources it needs; helps the team with expertise as necessary.

- Mentor: acts as the team's coach and helping resource, and helps the team learn, practice, and achieve results.

Sample Team Leader Duties and Team Member Checklist slides are shown below; such resources and more are contained in Appendix A.

FIGURE 3

TEAM LEADER DUTIES

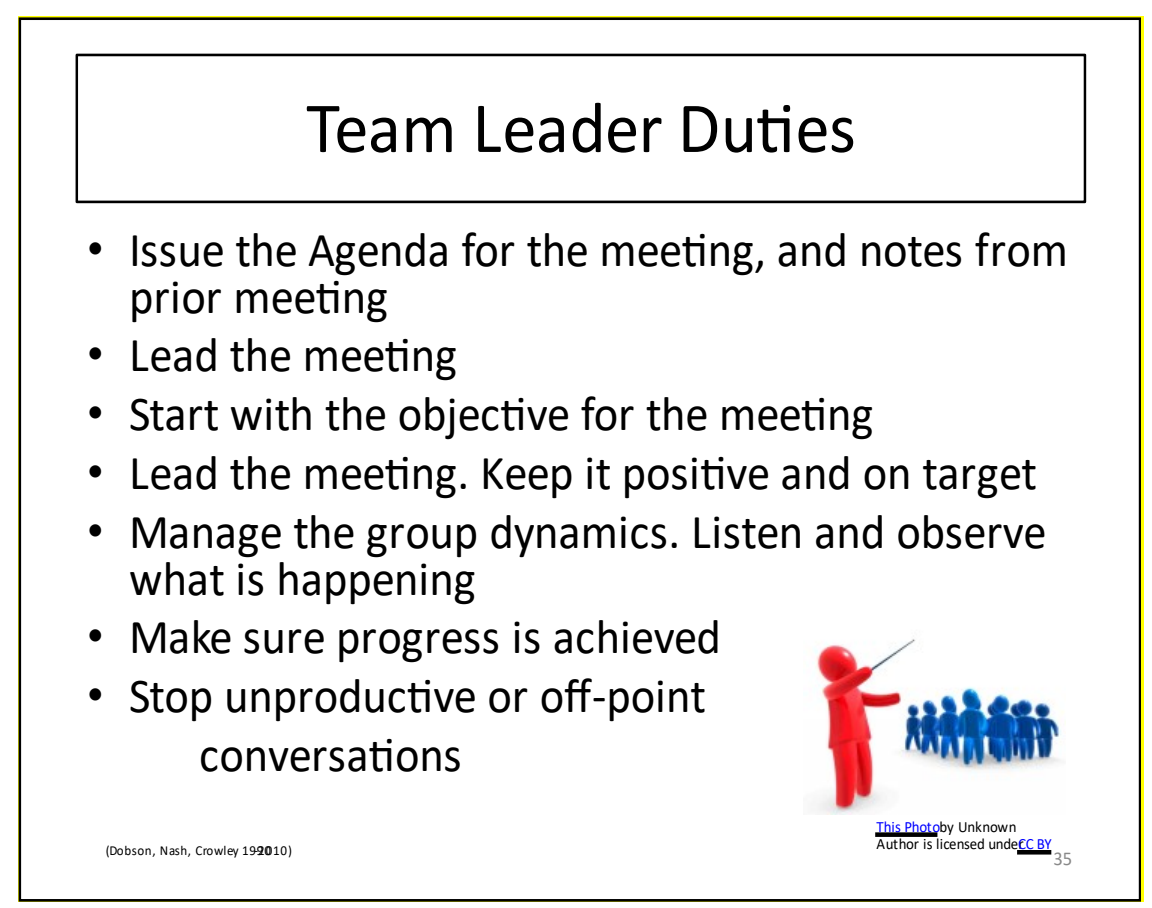




\section{Team Member Checklist}

\begin{tabular}{|l|l|l|}
\hline Did the Team Members & Yes & N/A \\
\hline 1. Show up on time? & & \\
\hline 2. Listen and participate? & & \\
\hline 3. Keep an open mind? & & \\
\hline 4. Offer knowledge and ideas? & & \\
\hline 5. Ask questions to aid understanding? & & \\
\hline 6. Limit distractions? & & \\
\hline 7. Take action items? & & \\
\hline 8. Show support to all other members? & & \\
\hline 9. Present their POV well? & & \\
\hline 10. Complete their past action items? & & \\
\hline
\end{tabular}

\section{Skills Required in Each Role}

Below is a listing (Figure 5) of seventeen team skills, which are developed through the teaching of this program and how they relate to each of the roles. It should be noted that all team member roles (including Leader, Facilitator, and Recorded, but excluding Mentor and Sponsor) are responsible for performing the duties of a team member. When one of the team members is assigned the role of Leader, Facilitator, or Recorder, they take on additional responsibilities for the team and the team process, as well as responsibility for continuing team member contributions to the team. The faculty sponsor may wish to occasionally rotate the Leader, Facilitator and Recorder assignments within the team in order to provide experience to all team members.

This sample is one view of the distribution of responsibilities. As instructors gain experience deploying team development, they may wish to adapt the skill matrix and the delegation of skills to match their style of teaching the team skills material.

FIGURE 5

SKILLS REQUIRED IN EACH ROLE

\begin{tabular}{|l|c|c|c|c|c|c|}
\hline Required Skill & Leader & Facilitator & Recorder & Member & Mentor & Sponsor \\
\hline 1. Defining team direction; Charter & $\mathbf{X}$ & & & & & $\mathbf{X}$ \\
\hline 2. Setting team goals and action plans & $\mathbf{X}$ & & & $\mathbf{X}$ & & \\
\hline 3. Analyzing work processes & $\mathbf{X}$ & $\mathbf{X}$ & $\mathbf{X}$ & $\mathbf{X}$ & & \\
\hline $\begin{array}{l}\text { 4. Monitoring members' } \\
\text { contributions }\end{array}$ & $\mathbf{X}$ & $\mathbf{X}$ & & & $\mathbf{X}$ & \\
\hline $\begin{array}{l}\text { 5. Controlling work and output } \\
\text { quality }\end{array}$ & $\mathbf{X}$ & & & & & \\
\hline 6. Teaching and helping teammates & $\mathbf{X}$ & & & $\mathbf{X}$ & $\mathbf{X}$ & \\
\hline 7. Measuring team progress & $\mathbf{X}$ & $\mathbf{X}$ & & $\mathbf{X}$ & $\mathbf{X}$ & \\
\hline
\end{tabular}




\begin{tabular}{|l|c|c|c|c|c|c|}
\hline 8. Including all teammates equally & $\mathbf{X}$ & $\mathbf{X}$ & & $\mathbf{X}$ & & \\
\hline 9. Keeping the team focused & $\mathbf{X}$ & $\mathbf{X}$ & & & & \\
\hline 10. Monitoring the team's activities & $\mathbf{X}$ & $\mathbf{X}$ & $\mathbf{X}$ & $\mathbf{X}$ & & \\
\hline 11. Sharing data and info with team & $\mathbf{X}$ & & & $\mathbf{X}$ & $\mathbf{X}$ & $\mathbf{X}$ \\
\hline $\begin{array}{l}\text { 12. Providing feedback to team } \\
\text { members }\end{array}$ & $\mathbf{X}$ & $\mathbf{X}$ & & $\mathbf{X}$ & $\mathbf{X}$ & $\mathbf{X}$ \\
\hline 13. Identifying team problems & $\mathbf{X}$ & $\mathbf{X}$ & & $\mathbf{X}$ & $\mathbf{X}$ & \\
\hline $\begin{array}{l}\text { 14. Summarizing and developing } \\
\text { reports }\end{array}$ & $\mathbf{X}$ & & & $\mathbf{X}$ & & \\
\hline 15. Presenting results to Management & $\mathbf{X}$ & & & $\mathbf{X}$ & & $\mathbf{X}$ \\
\hline 16. Developing additional team skills & $\mathbf{X}$ & $\mathbf{X}$ & $\mathbf{X}$ & $\mathbf{X}$ & $\mathbf{X}$ & $\mathbf{X}$ \\
\hline $\begin{array}{l}\text { 17. Listening and responding to } \\
\text { members }\end{array}$ & $\mathbf{X}$ & $\mathbf{X}$ & & $\mathbf{X}$ & & \\
\hline
\end{tabular}

Forming the Team and Creating the Team Charter

The team charter is a short document that outlines a number of factors requiring definition before the team is structured and given an assignment. It defines the goals, timetables, responsibilities, processes, and resources for the team. Team Charters include such items as:

- Purpose of the team

- Team sponsor or requestor

- Team members and role assignments

- Goals and objectives; output required

- Time frame for producing results

- Financial and time resources available to the team

- Resource limitations

- Expected operating parameters

- How the output will be evaluated

- How the output will be presented

The Team Charter should be completed by the Sponsor of the team, who may wish to include the team leader and the team mentor in the development of the Charter. It should be completed before the team starts to meet, to present initial guidance to the team.

During the initial team meeting, team members should follow the below structure to facilitate team discussions and move through the first of the Tuckman stages - forming:

- Introduce members; review role assignments; get to know each other

- Review the agenda for the meeting

- Clarify the goal of the team; review team charter with sponsor

- Share contact information and methods - in person, by phone, on-line

- Establish expectations for completion of work assignments in a professional and timely manner

- Team outlines process they will follow. Ideas are generated. Action plans are established. Assignments are made.

- Completion and circulation of the work plan

- Set-up the next meeting and define individual deliverables for that meeting

- Complete minutes and list of action items (recorder)

- Review meeting minutes and set agenda for next meeting (leader and facilitator)

Goal Setting and Action Plans; Team Deliverables

Goals and Goal Setting - enhanced goal setting processes are introduced, using the SMART goals process (Specific, Measurable, Achievable, Realistic, Timely (Doran, 1981). Individuals and teams practice 
setting and writing goals for the team's work, their accounting education, and personal development. Goals are reviewed and critiqued in class.

Students then create action plans and establish a defined process path for achieving their goals. Practice exercises are included, based on the goals established above. Again, small teams review and perform peer critiques of goals and action plans.

\section{Performance Measurement}

Performance measurement (White, 2018) is a key function of any team. Goals for the team are established in the team charter, and may or may not have input from the team. Measures of goal performance should also be indicated in the team charter; if performance metrics are not established in the team charter, the team will establish appropriate performance measures and present them to the team sponsor, or to the individual(s) responsible for the team.

Performance measures will typically include measures from the following five categories:

FIGURE 6

\section{PERFORMANCE MEASUREMENT CATEGORIES}

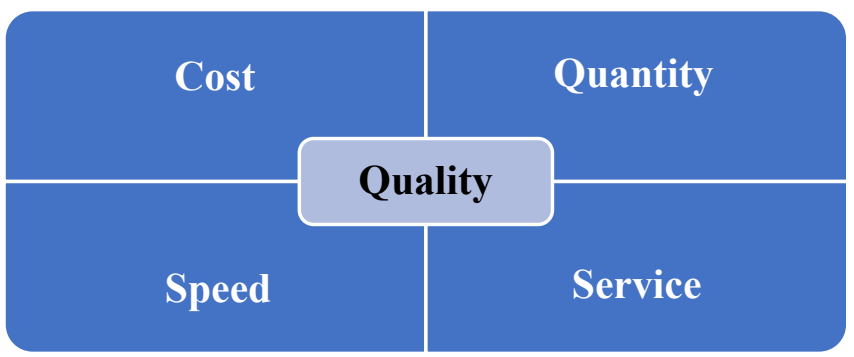

Examples are provided in Appendix A. In addition, the team clarifies their goal and action plans for the team, and submits them to the instructor for review.

\section{Setting a Meeting Agenda}

Agendas are the roadmap for the meeting. They tell the team where to start, what path to follow, and where to end. The agenda is prepared by the team leader and should include review of prior meeting minutes, discussion of items left open from the prior meetings, presentation of individual team members' work, and discussion of how to best proceed to meet the goals established in the team charter. A time limit for each stage of the agenda is established. Sample agendas are provided in Appendix A.

\section{Conducting an Effective Team Meeting}

An effective team meeting would encompass the following procedures:

- Before the meeting - all team members review the notes from the last meeting and the agenda for the next meeting. Team members ensure their individual work assignments are completed in a quality manner and are ready to present to the team.

- Start on time.

- Review any open items from last meeting; resolve them as necessary.

- Review current progress toward goals.

- Use PDCA cycle (see learning outcome 16) to determine next steps.

- Develop any new ideas or requirements for the project.

- Appendix A includes eight ways to develop new ideas in a meeting.

- Select person responsible for each action step.

- Determine action step output required, and timing for work to be completed.

- Review any group process issues or difficulties. 
- Adjourn meeting. Recorder finalizes minutes for the leader to review.

There are two optional team exercises included in Appendix A, taking approximately one hour each. They can provide your students with practice forming a team, conducting a team meeting, and idea generation. All team roles are practiced within these exercises.

\section{Team Project Timing and Measurement of Progress and Results}

As the team continues to work, the leader should review the schedule for the project, and determine if the work being produced is on schedule and of sufficient quality to meet the team's objectives. The leader may wish to involve others in the review, such as the mentor, the facilitator, or a team member. The leader's observations on progress should be discussed with the team at each meeting.

Performance measures and charting of performance will be updated as time, resources, and group progress occurs. If any one member of the group is not fulfilling their responsibilities, the leader should review (in private) that observation with the individual as soon as possible. Work may need to be reallocated based on team goals.

The team will continue to work until defined results are achieved and subject to the project plan, timetable and budget (both time and money). The team mentor or sponsor will watch over new teams, to ensure that required progress is being made toward the goal and schedule.

\section{Adjournment of Team}

At the end of the team project, students will be asked to reflect on their team experience.

- Students will complete individual assessments of team performance including what went well and what needs to be improved. Project assessment form is provided below in Table 9.

- Students complete a peer evaluation of team members' contributions, including documenting whether peers met pre-defined tasks for their roles. These peer evaluations are used by the instructor to determine if any differentiation in grade scores is necessary between team members. (See Appendix B).

- Students update their individual ePortfolio with their team roles, observations and significant deliverables. Students may wish to document their experience as if responding to a behavioral interviewing question about team experience.

- If significant results are achieved by the team, a recognition or celebratory event may be held.

\section{Module Two}

Module Two contains learning outcomes fifteen through twenty-three. Module Two should be placed in the second half of the accounting curriculum, preferably in the Junior year. This will allow students the opportunity to practice what they learned in Module One. The focus of Module Two is on how to effectively manage teams to achieve results, including critical thinking of how to meet team goals, how to improve team and work processes, and includes diagnosis and management of problem issues which may occur within the team. The module concludes with explicit relation of the team skills to the workplace and how students can leverage their team experience in interviews for internships and full-time employment.

As above, Appendix A follows the same numbering and topic flow as listed below. As such, we begin the numbering with topic number 15.

\section{Process Analysis and Mapping}

Students learn and practice basic process mapping and understand how it is extensively used in business settings. Simple to complex process map samples are provided in Appendix A. Teams analyze an accounting process and map it. Their work assignment for the week includes a second process mapping exercise. Understanding process management skills will enhance the student's future ability to work in interdisciplinary groups with professionals from operations, manufacturing, computer technology, engineering and other technical personnel as they participate on work teams. 


\section{Process Improvement - The Deming Wheel of Continuous Improvement}

W. Edwards Deming, a statistician, professor and consultant (Deming, 2000) is largely credited as one of the prime contributors to the field of Statistical Quality Control, which he pioneered in World War II, and later used to help Japan become a quality leader in the world over the following 40 years. In fact, the Deming Medal is still awarded today in Japan for the companies with the highest measured quality.

Deming also defined an improvement methodology (PDCA - The Deming Cycle or Deming Wheel), which was intended for use in process improvement - later labelled continuous improvement. Having worked with this for years, we find that it can be a major contributing resource to managing any project or personal effort. Once a person knows how to use PDCA, it can be one of their most useful tools in the business and personal life tool kit. The four steps are:

- Plan: think before you take action, and make a plan; detail of plan will vary based on the importance of the project (we have seen one-page plans, and 1000-page plans).

- Do: take action; carry out your plan.

- Check (or Study and Collect Data): Measure how you and your team are doing on your plan.

- Act: based on your Check assessment, make revisions in the Plan.

- Continue the cycle until you reach your goal. Then, PDCA your next level of achievement on this goal, or on another goal.

\section{FIGURE 7}

THE DEMING CYCLE FOR PROCESS AND CONTINUOUS IMPROVEMENT (DEMING, 1986)

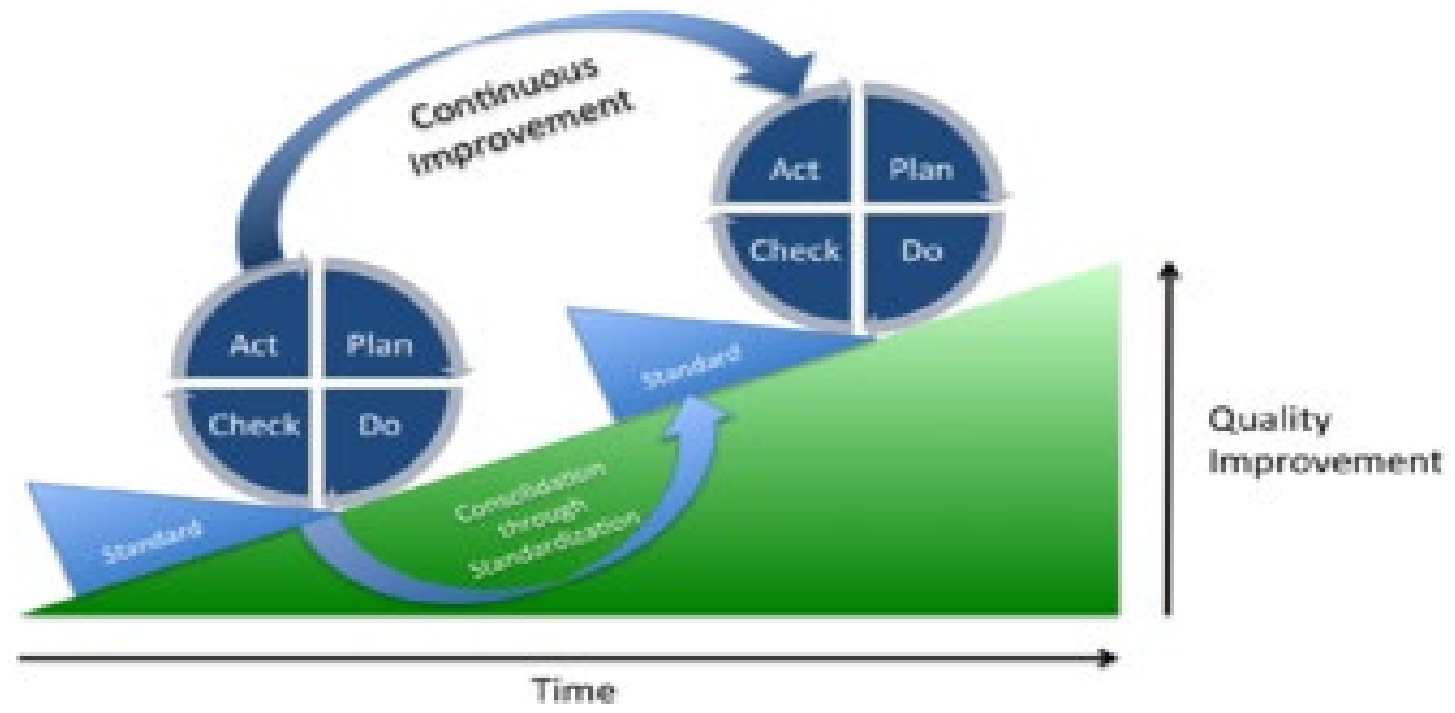

This Photo by Unknown Author is licensed under CC BY-SA

\section{Force Field Analysis}

Force field analysis (Lewin, 1997; Swanson, et al., 2014) is a highly useful tool for analyzing the driving (helping) and restraining (hindering) forces effecting a process being analyzed. It is also very useful in determining the roadblocks to team project achievement, how strong they are, and how to eliminate those detrimental forces. It has been widely used in change management.

Students view and discuss the model, then practice an exercise - derived from their own experience where they map helping and hindering forces, determine the strength of each, and develop a responding action plan. Force field analysis is a useful project skill in any university, professional, or personal project. 


\section{FIGURE 8 \\ FORCE FIELD ANALYSIS}

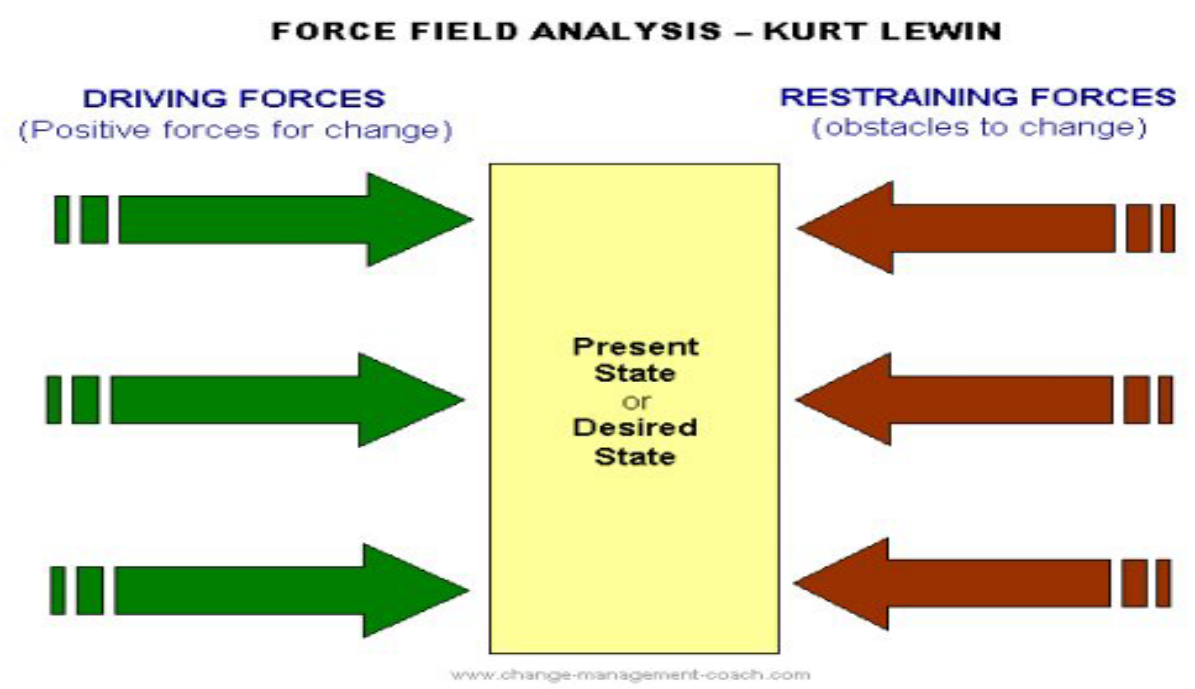

This Photo by Unknown Author is licensed under CC BY-NC-ND

\section{Overcoming Team Problems}

A listing of commonly encountered team problems is provided (Nash, et al., 2005; Scholtes, et al., 2018; Tannenbaum \& Salas, 2021), along with a recommended approached for handling the team problems. The problems are drawn from the authors' teamwork experience, and from auditing, consulting, and financial-related business management. The instructor leads an analysis as to how to handle each issue.

Team problems that are relevant to undergraduate accounting students include:

- Confusion as to roles, responsibilities, actions at the individual and team level

- Conflict and tension between team members

- Lack of clarity of direction. Progress not occurring

- Ego-centric behavior, seen as dominance and talking over team members

- Failure to listen to others.

- Arguments among team members

- Non-inclusive behavior and discriminatory bias

- Non-participation in meetings for cultural reasons or fear of embarrassment

- Failure to complete work assignments in a timely or quality manner

- Presentation of opinions and beliefs as facts

- Lack of maturity in team work, discussions, work behaviors and results

- Team cannot seem to move forward or get things done

- Members not excited about team participation

- Team is bored with coming to team meetings

- Members are challenging the leader for control

- Team is losing focus and straying off target

- Team wants to move on to an unrelated subject

Suggested responses are provided for each team problem in Attachment A, including an overarching decision to: do nothing/let it work itself out; private conversation with an individual; discuss with the Mentor; and hold a general team discussion. A variety of outcomes are also discussed: problem is resolved, follow-up needed, no improvement, accept the behavior and note it on rating feedback, and don't accept the behavior and dismiss the person from the team. 


\section{Effective Listening, Reflecting and Responding}

This section is drawn from the consulting work of the authors, and presents the best practices for listening to client issues, and drawing out information from clients and other employees. These practices reflect the roles of the speaker, the listener, and the filtering process that occurs in discussions. Listening, reflecting, questioning and responding skills are discussed and practiced, and a guideline is presented to students. Particular focus is placed on these skills in relation to auditing and consulting.

The instructor should review the communications training that is typically part of undergraduate studies. The topic may be sufficiently covered in that course; if so, this section can be a brief review.

\section{Providing and Receiving Constructive Feedback}

There are right ways and less-right ways to provide feedback to others, and to receive and respond to feedback from others. In this section, we review both positive responses, which will be modeled, as well responses which are less appropriate, and may draw disappointment, defensiveness, or anger from the other party. Cases from practical accounting experience are presented in Appendix A.

\section{Ongoing Role of the Sponsor and Mentor}

The mentor is a key support role for the teams in providing guidance, direction, assistance and support to the teams. This role will generally be filled by the course faculty, or instructional assistants, if available. The role requires skills in observation, questioning, guidance, problem solving and team skills.

The intention of the mentor is to keep the teams on track to completing their objective in the most efficient and effective manner. The mentor should stick to the outlines provided by the course, and should not be introducing new methods at this time. Keep it simple while the groups are learning.

The primary role of the sponsor, following the chartering of the team, is to receive updates from the team leader and mentor regarding the progress of the team, and to suggest alternative approaches, or additional resources, as necessary. The final results of the team, and a summary of what the team learned from the process, are generally presented to the sponsor.

\section{Utilizing Team Skills in Post Graduate Life}

Through teamwork skills training, teamwork practice opportunities and tracking of student progress, graduating students will have the background to excel at answering teamwork-based questions during interviews and performing well in teams in their professional lives. While the typical college graduate may refer generally to having worked on group projects (and, in the authors' experience, usually remark how much they disliked the experience), accounting students graduating with the team skills identified in this paper will have substantially better responses. This topic includes discussion of how to use the students' experience, which they have been documenting since Module One, to prepare their resumes and to practice for behavioral interview questions such as, "Do you have any experience working in teams"?

Your response: "Yes, I have extensive teamwork training and experience. Our accounting program at the university included training in 23 team related skills - on how to form a team; how to work as a team; how to solve team problems; how to define a work process; and how to make improvements to that work process. We had at least 8 team projects in our accounting courses - each one of them graded for efficiency and effectiveness. I can show you my portfolio if you would like, indicating the training received, the projects completed, and my team ratings. While I have more to learn on teams when I join your company, I think I have a good base with which to start." When starting a new job, former students' teammates will respect the fact they received training and experience as part of their accounting education.

\section{How to Be a Star at Teamwork}

Each student can work toward being a star at teamwork, both in their accounting studies at college and as they enter the workforce, by learning and practicing the skills while working in teams, and as they participate in other life experiences. For example:

- Having a goal and plan is frequently a good idea;

- Knowing how to get that plan done - an action plan - can save a lot of trial and error; 
- Treating others with respect is a strong life asset;

- Working well with all types of people is very helpful;

- Respecting differences and diversity are important every day;

- Knowing and using process mapping is a great skill for improvement projects;

- Knowing how to solve communication problems is ever important; and,

- Listening to others, and respecting their contributions, builds strong relationships.

The team skills developed as part of the accounting curriculum are really life skills. And they are only the beginning. You have heard the phrase, "Becoming a lifelong learner," many times. Teamwork, and the skills embodied within teamwork, are a focus for developing lifelong skills. Work on teams; work with others; improve your skills; keep reading and developing. Hard work and practice, combined with intelligence and a dash of good fortune, are still keys to success.

\section{ASSESSMENT OF TEAM SKILLS}

The skills presented in this paper, and its associated learning program (Appendix A) were derived from a needs' analysis from a faculty work team, and were developed by a faculty/practitioner team which collectively has developed team learning and taught team skills to more than 3,000 people, and has many years' experience teaching university students. We believe that this provides the authors sufficient credibility to establish qualitative validity to the paper and the program.

To assess the qualitative validity of the teamwork education process and materials, the following three methods are recommended:

- Student Self-Evaluation: Students perform a periodic self-evaluation of their team knowledge and skills competencies. They utilize this assessment to set goals for gaining competency in through team experiences throughout their coursework. Students should, at a minimum, assess at the beginning of Module One and at the end of Module Two (although, self-assessment each semester or academic year may be beneficial). While the purpose of this self-assessment is to aid student's in identifying their areas for improvement, faculty may gather this information to determine students' beliefs about the benefits of the team skills curriculum. Based on the ratings on the Teamwork Knowledge Self-Assessment, areas which are indicated as Needing Development, or as Satisfactory, may deserve a development plan (see SMART goals for format). The student should select two to three areas for development. (Selecting more than three areas for improvement at any one time increases the likelihood that the areas are not sufficiently addressed). Figure 9 presents the Teamwork Knowledge Self-Assessment.

- Student Peer-Evaluations: A peer rating process will be conducted at the end of each major team project, whereby team members rate each other on 10 skills and contributions made to the team process. These peer rating forms will be collected by the instructor, and will be analyzed, summarized and reported upon. Faculty may choose to use these forms to assign differential grades among team members. A sample completed Peer Rating Form is shown as Figure 10, below. A blank Peer Evaluation form suitable for instructor tailoring, is provided in Appendix B. (The presented Peer Rating Form is similar in nature and content to the CATME Teamwork Rating Scale. There is substantial overlap between CATME's primary 16 rating skills and the content presented in this paper's team skills curriculum. While Figure 10 is tailored to the material presented in this paper, instructors may substitute this Peer Rating Form with the CATME evaluation tool with little adjustment necessary).

- Teamwork Learning Outcomes Assessment: At some point after the provision of Module Two, faculty should assess whether students have achieved the learning outcomes related to the two modules in the team skills curriculum. This assessment can be of several types, such as review of a sample of student ePortfolios, reflection paper, or multiple-choice exam (Reinig, et al., 2014; Volkov \& Volkov 2015). Regardless of the method, such assessments are crucial to evaluate the effectiveness of the implementation of the team skills curriculum at your 
university, to inform the faculty's continuous improvement of the team skills program, and to document the effectiveness of the program (for example, to use for accreditation). An example multiple choice exam is provided in Appendix C.

\section{FIGURE 9 \\ TEAMWORK KNOWLEDGE SELF-ASSESSMENT}

\begin{tabular}{|c|c|c|c|}
\hline Skill Being Assessed for (Name): & \begin{tabular}{l|} 
Needs \\
Development
\end{tabular} & $\begin{array}{l}\text { Satisfactory- } \\
\text { Meets needs }\end{array}$ & $\begin{array}{l}\text { Highly } \\
\text { Skilled }\end{array}$ \\
\hline 1. Can define the developing roles of accountants. & & & \\
\hline 2. Can define why and how business uses teams. & & & \\
\hline 3. Can define the stages of team development. & & & \\
\hline 4. Can define roles on a team. & & & \\
\hline 5. Can define goal setting methods. & & & \\
\hline $\begin{array}{l}\text { 6. Can define methods for team performance } \\
\text { measurement. }\end{array}$ & & & \\
\hline 7. Can define methods which increase team success. & & & \\
\hline $\begin{array}{l}\text { 8. Can describe constructive and destructive feedback, } \\
\text { with examples. }\end{array}$ & & & \\
\hline 9. Can utilize effective listening skills. & & & \\
\hline $\begin{array}{l}\text { 10. Can describe brainstorming and other methods for } \\
\text { idea development. }\end{array}$ & & & \\
\hline $\begin{array}{l}\text { 11. Can discuss how meetings get off-track, and how to } \\
\text { get them back on-track. }\end{array}$ & & & \\
\hline $\begin{array}{l}\text { 12. Can describe the purpose of a team member } \\
\text { contract and provide examples. }\end{array}$ & & & \\
\hline $\begin{array}{l}\text { 13. Can describe the role and need for a team } \\
\text { mentor/sponsor. }\end{array}$ & & & \\
\hline $\begin{array}{l}\text { 14. Can provide a comprehensive list of team } \\
\text { experiences in college, during internships, and } \\
\text { other work. }\end{array}$ & & & \\
\hline $\begin{array}{l}\text { 15. Can explain at least } 3 \text { team problems they have } \\
\text { encountered, and how they addressed them. }\end{array}$ & & & \\
\hline $\begin{array}{l}\text { 16. Can provide copies of presentations and evidence } \\
\text { of team results. }\end{array}$ & & & \\
\hline $\begin{array}{l}\text { 17. Can describe how s(he) maintains and reflects a } \\
\text { positive attitude. }\end{array}$ & & & \\
\hline $\begin{array}{l}\text { 18. Can provide a personal development plan, and } \\
\text { detail goals set and results achieved during college } \\
\text { terms. }\end{array}$ & & & \\
\hline $\begin{array}{l}\text { 19. Can provide team journal or ePortfolio which } \\
\text { documents team participation throughout college } \\
\text { terms. }\end{array}$ & & & \\
\hline $\begin{array}{l}\text { 20. Can reflect team experiences and benefits in oral } \\
\text { communication (such as a job interview). }\end{array}$ & & & \\
\hline
\end{tabular}


FIGURE 10

PEER RATING FORM OF TEAM PERFORMANCE - SAMPLE

\begin{tabular}{|c|c|c|c|c|c|c|}
\hline \multicolumn{2}{|c|}{ PEER RATING FORM } & \multicolumn{5}{|c|}{ Class: Intermediate Accounting II } \\
\hline \multicolumn{2}{|c|}{ Reviewer Name: Gabriela } & \multicolumn{5}{|c|}{ Date: Fall 2021} \\
\hline \multirow[b]{2}{*}{$\begin{array}{l}\text { Rating } \\
\text { Category }\end{array}$} & \multirow[b]{2}{*}{ Rating Criteria } & \multicolumn{2}{|c|}{$\begin{array}{l}\text { 1: Exemplary } \\
\text { 3: Average } \\
\text { 5: Poor }\end{array}$} & \multicolumn{3}{|c|}{$\begin{array}{l}\text { 2: Above Average } \\
\text { 4: Below Average }\end{array}$} \\
\hline & & Juan & Maria & Leroy & Robert & Malak \\
\hline $\begin{array}{l}\text { Work } \\
\text { contribution }\end{array}$ & $\begin{array}{l}\text { 1. Completed work assignments } \\
\text { with acceptable quality and on } \\
\text { time }\end{array}$ & 3 & 1 & 2 & 4 & 2 \\
\hline Communication & $\begin{array}{l}\text { 2.Communicated well with all } \\
\text { teammates. Shares information }\end{array}$ & 4 & 1 & 2 & 3 & 3 \\
\hline Helps Others & $\begin{array}{l}\text { 3.Helped other teammates as } \\
\text { required }\end{array}$ & 3 & 2 & 2 & 3 & 3 \\
\hline $\begin{array}{l}\text { Shares } \\
\text { Information }\end{array}$ & $\begin{array}{l}\text { 4.Taught and shared team and } \\
\text { project skills with teammates }\end{array}$ & 3 & 2 & 2 & 3 & 2 \\
\hline Feedback & $\begin{array}{l}\text { 5.Provides appropriate feedback, } \\
\text { and listens well to others }\end{array}$ & 4 & 2 & 2 & 3 & 3 \\
\hline Positive Change & $\begin{array}{l}\text { 6. Promotes and helps develop } \\
\text { positive changes to the team and } \\
\text { the work }\end{array}$ & 3 & 1 & 1 & 4 & 3 \\
\hline Skill sharing & $\begin{array}{l}\text { 7.Helps the team develop skills } \\
\text { and knowledge of team processes }\end{array}$ & 3 & 2 & 2 & 3 & 2 \\
\hline Team process & $\begin{array}{l}\text { 8.Helps to keep the team efficient - } \\
\text { focused and on track }\end{array}$ & 3 & 2 & 2 & 3 & 2 \\
\hline $\begin{array}{l}\text { Summarize } \\
\text { progress }\end{array}$ & $\begin{array}{l}\text { 9.Helps the team summarize } \\
\text { results and develop the final } \\
\text { report }\end{array}$ & 4 & 1 & 1 & 3 & 2 \\
\hline $\begin{array}{l}\text { Report and } \\
\text { Presentation }\end{array}$ & $\begin{array}{l}\text { 10.Helps the team prepare and } \\
\text { present the final report }\end{array}$ & 3 & 2 & 1 & 3 & 4 \\
\hline & Comments: & $\begin{array}{r}\text { Total } \\
\mathbf{3 3} \\
\end{array}$ & 16 & 17 & 32 & 26 \\
\hline
\end{tabular}

\begin{tabular}{|c|l|c|}
\hline Aggregate Score & $\begin{array}{c}\text { Qualitative Assessment of Team Member } \\
\text { Contribution }\end{array}$ & $\begin{array}{c}\text { Teamwork Effectiveness } \\
\text { Grade Factor }\end{array}$ \\
\hline $10-17$ & Superior Contributor & $\times 125 \%$ \\
\hline $18-26$ & Above Average Contributor & x $110 \%$ \\
\hline $27-34$ & Average Contributor & x $100 \%$ \\
\hline $35-42$ & Below Average Contributor & $\times 75 \%$ \\
\hline $42-50$ & Little to no value added & x $0 \%$ \\
\hline
\end{tabular}




\section{LOGISTICS OF IMPLEMENTING TEAM SKILLS IN ACCOUNTING}

\section{Training of Professors and Instructors}

Studies (Bryant \& Albring, 2006; Howieson, 2003; Lawson, et al., 2015) have indicated that primary reasons why proper team and other 'soft' skills are not taught in most accounting curriculums include:

- Teaching staff members do not consider the generic skills to be as important as the technical skills of accounting,

- The accounting curriculum is already completely full (Kavanaugh, 2009), and,

- No one has developed team skills within the teaching staff.

We believe we have firmly addressed the requirement and urgency that accounting programs incorporate team skills training in earnest, despite the fact this content may displace a minor amount (4 to 5 hours in total) of technical accounting content.

We have not yet addressed the issue of accounting instructor competency. While most accounting professors have deep accounting-relevant knowledge, most have little to no formal training in teamwork skills. To develop the professors' skills, it will be necessary for them to up-skill their knowledge of teams. We believe this paper provides a sufficient roadmap to incorporate the requisite team skills classroom training to instructors and faculty, and recommend that they complete this training. Further, faculty can supplement with outside materials which they develop, or from their own research and cases.

This training and additional resources can be provided by a trained and knowledgeable professor at the university, by the sponsor or mentor of the program at the university (assuming someone at the university has the expertise), or by an external resource. Most universities have an individual with expertise in teamwork and/or interpersonal skills on campus, but that individual is frequently not within the accounting department.

Additionally, the professors of the two team skills-learning modules must work together to smooth the transition of team skills modules within their courses, so that they may cross reference team materials to the other courses in a seamless manner. Once this is accomplished, the team skills content can be integrated into additional accounting courses through practicing the previously learned content in team assignments.

It is recommended that the instructors 'team teach' or, at the very least, closely collaborate on these team modules for a few iterations, so that they can learn from each other and better ensure the seamless flow from one course to another.

\section{Development of Course Material}

Time will have to be allotted for curriculum development by the professors involved in the courses which incorporate the team modules, and to adapt their case-study work appropriately. Each case or group assignment should be annotated with written detail of how team skills will be developed, how team critiques will be completed, and which teamwork and interpersonal skills will be improved. The reference section of this paper provides adequate content resources to guide this development. Regardless of resources utilized, the professors must use content, language and exercises which are culturally appropriate to their own university. This 'branding' of content and methods will be more meaningful to the students, and will enhance their material retention, over strictly commercial content.

Lawson, et al., (2015) present a written framework whereby each technical accounting module or case study includes explicit identification of the teamwork and interpersonal foundational skills which will be developed as part of the learning module. Some faculty may be prepared to do this today, others will need further education or coaching. Leveson (2000) presents that we must develop a common language between graduating accountants and the professional environment if we expect our students to successfully compete in a competitive job market, and, as such, teaching materials should be crafted with this in mind.

\section{The Two Module Format for Teaching Team Skills}

This paper utilizes two accounting courses (geared towards students in their freshmen/sophomore and junior years) to fulfill the teamwork-in-accounting requirements. This approach requires coordination among the selected accounting faculty, as well as with professors and chairpersons representing any other 
involved collegiate departments. All accounting students would be required to take these two courses; some business schools may wish to require these teams' modules in courses required for all business majors.

\section{Pre-Reading Work Assignment}

As part of Module One of the team skills training, students should be provided a booklet of reading materials regarding teams and team development within the two modules. This will incorporate a description of the teams' skills process, including: a definition of what team development encompasses, how it will be carried out within the accounting curriculum, what content will be included, post-graduate employer expectations, and the tracking methods for team skills which will make the student more employable. Team and individual expectations will be defined, as well as course resources. A team-skills tracking mechanism that allows individuals to track their team notes over the course of their time in college, will be explained (many learning management systems, such as Canvas and Blackboard, have built in functionality to allow for such resources to be provided to students outside of their normal coursework). All of this material can be extrapolated from the above pages, and from Appendix A.

Within Appendix A, we provide a listing of 'green shaded' slides, which indicate short-course recommended content. The instructor may wish to indicate these 'green slide' materials as pre-reading. This paper would also be useful pre-reading.

As another option, the instructor could e-forward the full presentation to the accounting students, and then select pre-work, as well as weekly assignments, using this saved PowerPoint file. The PowerPoint will then provide the student with a reference copy of team skills for future use.

\section{Grading of Team Projects}

Students will be required to work within teams to complete projects. At the end of substantial projects, the team members will complete self and peer evaluations, detailing their personal contribution to the team's results, and also ranking the relative contribution of the team members. This will allow for differentiation in grading (Hilton \& Phillips, 2010).

Development of tools and methods for grading work assignments and recognizing varying levels of contributions from team members is recommended. Huddleston and Pfaff (2003) indicate that students are often caused to dislike teamwork because of unfair grading procedures, whereby a low contributing team member receives the same grade as other team members. Feichtner and Davis (1984) support peer evaluations so that relative contributions from each team member can be discerned.

Wilcoxson (2016) repeats these concerns regarding free-riding by some team members, and suggests a signed learning contract at the beginning of a course which defines peer rating for the project. With the benefit of a formal structure of what it means to be a team instead of a group, as well as requiring students to clearly define their role in groups and peer feedback, free-riding issues can be minimized.

\section{SUMMARY AND CONCLUSIONS}

The demand for teamwork education and skill development has been identified in accounting research for at least 20 years. Ongoing feedback from employers indicates that most of our universities' accounting programs have not yet fulfilled the team skills requirements of employers.

Accounting programs, heavily burdened with technical content and time constraints, have not found the time to determine the specific relevant teamwork skills and learning outcomes required, develop the team programs, create the educational materials for teaching, nor to adapt a sufficient amount of class work to team skills application. Merely working in groups does not satisfy employers' team-skills requirements, meet the goals laid out in the AICPA Business or Professional Competency frameworks, or the requirements of the AACSB.

The amount of research and writing on teams and teamwork is overwhelming. It would be very difficult for an individual accounting professor to study this teams' field and develop a teams' curriculum, in addition to their already existing demands to keep their accounting courses contemporary with increasing content and methodological demands. 
This paper synthesizes the body of study on teams into the critical principles that must be understood to start up a 'teams in accounting' educational process, with associated practice and development exercises. Specifically, we define the course content for learning and practice of team skills, and then proceed to provide that content, as well as tools for peer skill measurement and feedback. The paper also provides for training the professors in team skills, student tracking of personal accomplishments in the teams' realm, and for team - oriented discussion in a job interview setting.

\section{REFERENCES}

Agarwal, D., Bersin, J., Lahiri, G., Schwartz, J., \& Volini, E. (2018). The symphonic C-suite: Teams leading teams. 2018 Deloitte Global Human Capital Trends, pp. 17-22.

AICPA and American Accounting Association. (2015). Pathways Commission on Accounting Higher Education: Charting a National Strategy for the Next Generation of Accountants.

Albrecht, W.S., \& Sack, R.J. (2000). Accounting Education: Charting the Course through a Perilous Future. Accounting Education Series, V16.

American Institute of Certified Public Accountants (AICPA). (2018). Pre-Certification Core Competency Framework.

Arumugam, V., Antony, J., \& Kumar, M. (2013). Linking learning and knowledge creation to project success in six sigma projects: An empirical investigation. International Journal of Production Economics, 141, 388-402.

Association to Advance Collegiate Schools of Business. (2020). AACSB Guiding Principles and Standards for Business Accreditation.

Ballantine, J., \& Larres, P.M. (2009). Accounting Undergraduates' Perceptions of Cooperative Learning as a Model for Enhancing their Interpersonal and Communication Skills to Interface Successfully with Professional Accountancy Education and Training. Accounting Education, 18(4-5), 387-402.

Bassam, M., \& Al-Attar, A. (2020). Accounting Curricula in Universities and Market Needs: The Jordanian Case. Journals.Sagepub.com, 1(12), 1-9.

Behn, B.K., Ezzell, W.F., Murphy, L.A., Rayburn, J.D., Stith, M.T., \& Strawser, J.R. (2012). The Pathways Commission on Higher Education: Charting a National Strategy for the Next Generation of Accountants - Executive Summary. Issues in Accounting Education, 27(3), 595600 .

Bergeil, B.J., Bergeil, E.B., \& Balsmeier, R. (2008). Nature of virtual teams: A summary of their advantages and disadvantages. Management Research News, 31(2), 99-110.

Birrel, B. (2006). The Changing Face of the Accounting Profession in Australia. CPA Australia.

Black, W.H. (2012). The Activities of the Pathways Commission and the Historical Context for Changes in Accounting Education. Issues in Accounting Education, 27(3), 601-625.

Bloch, J., Brewer, P.C., \& Stout, D.E. (2012). Responding to the Leadership Needs of the Accounting Profession: A Module for Developing a Leadership Mindset in Accounting Students. Issues in Accounting Education, 27(2), 525-554.

Bryant, S.M., \& Albring, S.M. (2006). Effective Team Building: Guidance for Accounting Educators. Issues in Accounting Education, 21(3), 241-265.

Casper, W.C. (2017). Teaching Teamwork Skills in Higher Education. Journal of Higher Education Theory and Practice, 17(6), 53-55.

Chaffer, C., \& Webb, J. (2017). An evaluation of competency development in accounting trainees. Accounting Education, 26(5-6), 431-458.

Chowdhury, T., \& Murzi, H. (2019). Literature Review: Exploring Teamwork in Engineering Education. Conference paper; submitted for publication, pp. 1-9.

Christensen, J., Harrison, J.L., Hollindale, J., \& Wood, K. (2019). Implementing team-based learning (TBL) in accounting courses. Accounting Education, 28(2), 195-219.

Daff, L., de Lange, P., \& Jackling, B. (2012). A Comparison of Generic Skills and Emotional Intelligence in Accounting Education. Issues in Accounting Education, 27(3), 627-645. 
Dahal, R.K., (2019). Changing Role of Management Accounting in 21st Century. Review of Public Administration and Management, 7(264), 1-8.

De Leede, J., Nijhof, A.H., \& Fisscher, O.A.M. (1999). The Myth of Self-Managing Teams: A Reflection on the Allocation of Responsibilities between Individuals, Teams, and the Organization. Journal of Business Ethics, 21, 203-215.

Deming, W.E. (2000). Out of the Crisis. MIT Press.

Doran, G.T. (1981). There's a SMART way to write management's goals and objectives. Management Review, 70(11), 35-36.

Douglas, S., \& Gammie, E. (2019). An investigation into the development of non-technical skills by undergraduate accounting programmes. Accounting Education, 28(6), 304-322.

Driskell, J.E., Goodwin, G.F., Salas, E., \& O’Shea, P.G. (2006). What Makes a Good Team Player? Personality and Team Effectiveness. Group Dynamics: Theory, Research and Practice, 10(4), 249-271. American Psychological Association.

Feichtner, S.B., \& Davis, E.A. (1989). Why some groups fail: A survey of students' experiences with learning groups. Journal of Management Education, 9(4), 58-73.

Gammie, B., Gammie, E., \& Cargill, E. (2002). Personal skills development in the accounting curriculum. Accounting Education, 11(1), 63-78.

Gos, K. (2015). The Key Advantages and Disadvantages of Matrix Organization Structures. Source not known.

Gray, F.E. (2010). Specific Oral Communication Skills Desired in New Accountancy Graduates. Business Communication Quarterly, 73(1) 40-71.

Hilton, S., \& Phillips, F. (2010). Instructor-Assigned and Student-Selected Groups: A View from Inside. Issues in Accounting Education, 25(1), 15-33.

Hitt, L.M., \& Brynjolfsson, E. (1997). Information Technology and Internal Firm Organization: An Exploratory Analysis. Journal of Management Information Systems, 14(2), 81-100.

Hobson, C.J., Strupeck, D., Griffin, A., Szostek, J., \& Rominger, A.S. (2014). Teaching MBA Students Teamwork and Team Leadership Skills: An Empirical Evaluation of a Classroom Educational Program. American Journal of Business Education, 7(3), 191-212.

Howieson, B. (2003). Accounting practice in the new millennium: Is accounting education ready to meet the challenge? The British Accounting Review, 35, 69-103.

Huddleston, P., \& Pfaff, E. (2003). Does It Matter if I Hate Teamwork? What Impacts Students Attitudes toward teamwork? Journal of Marketing Education, pp. 25-37.

Hughes, R.L., \& Jones, S.K. (2011). Developing and Assessing College Student Teamwork Skills. New Directions in Institutional Research, 149, 53-64.

Jackling, B., \& DeLange, P. (2009). Do Accounting Graduates' Skills Meet the Expectations of Employers. A Matter of Convergence or Divergence. Accounting Education, 18(4-5), 369-385.

Jones, G.E., \& Abraham, A. (2008). Preparing accountants for today's global business environment: The role of emotional intelligence in accounting education. Fifth Annual Conference of the American Society of Business and Behavioral Sciences, pp. 22-27.

Jones, R. (2014). Bridging the Gap: Engaging in Scholarship with Accountancy Employers to Enhance Understanding of Skills Development and Employability. Accounting Education, 23(6), 527-541.

Kavanagh, M., Hancock, P., Howieson, B., Kent, J., \& Tempone, I. (2009). Stakeholders perspectives of the skills and attributes for accounting graduates. Conference presentations for Accounting and Finance Association of Australia and New Zealand.

Kavanagh, M.H., \& Drennan, L. (2007). What skills and attributes does an accounting graduate need? Evidence from student perceptions and employer expectations. Grant Study for the CPA Australia to the University of Southern Queensland, Australia, pp. 1-23.

Kennedy, F.A., \& Dull, R.B. (2008). Transferable Team Skills for Accounting Students. Accounting Education, 17(2), 213-244. 
Klibi, M.F., \& Oussii, A.A. (2013). Skills and Attributes Needed for Success in Accounting Careers: Do Employers' Expectations Fit with Students Perceptions? Evidence from Tunisia. International Journal of Business and Management, 8(8), 118-132.

Langfred, C.W. (2007). The Downside of Self-Management: A Longitudinal Study of the Effects of Conflict in Trust, Autonomy, and Task Interdependence in Self-Managing Teams. Academy of Management, 50(4).

Lawson, R.A., Blocher, E.J., Brewer, P.C., Cokins, G., Sorenson, J.E., Stout, D.E., . . Wouters, M.J.F. (2014.). Focusing Accounting Curricula on Students' Long-Run Careers: Recommendations for an Integrated Competency-Based Framework for Accounting Education. Issues in Accounting Education, 29(2), 259-317.

Lawson, R.A., Blocher, E.J., Brewer, P.C., Morris, J.T., Stocks, K.D., Sorenson, J.E., . . Wouters, M.J.F. (2015). Thoughts on Competency Integration in Accounting Education. Issues in Accounting Education, 30(3), 149-171.

Lee, M.Y., \& Edmondson, A.C. (2017). Self-managing organizations: Exploring the limits of lesshierarchical organizing. Research in Organization Behavior, 37, 35-58.

Leroux, J.A., \& Lafleur, S. (1995). Employability skills: The demands of the workplace. The Vocational Aspects of Education, 47(2), 190-199.

Lewin, K. (1993). Defining the Field at a Given Time. Psychological Review, 50(3).

Lingard, R.W. (2010). Teaching and Assessing Teamwork Skills in Engineering and Computer Science. Systemics, Cybernetics and Informatics, 8(1), 34-37.

Loughry, M.L., Ohland, M.W., \& Woehr, D.J. (2014). Assessing Teamwork Skills for Assurance of Learning Using CATME Team Tools. Journal of Marketing Education, 36(1), 10-17.

Maali, B., \& Al-Attar, A.M. (2020). Accounting Curricula in Universities and Market Needs: The Jordanian Case. Journals.sagepub.com/home/sgo, 1(12), 1-12.

Marasi, S. (2019). Team Building: Developing Teamwork Skills in College Students Using Experiential Activities in a Classroom Setting. Organization Management Journal, 16(4), 324-337.

Martin, A., \& Bal, V. (2006). The state of teams. CCL Research Report. Greensboro, NC: Center for Creative Leadership.

McGuigan, N., \& Kern, T. (2016). CreActive Accounting Education: Visioning Future Oriented Accounting Programs through a Reflective Unlearning of Current Practice. Journal of University Teaching and Learning Practice, 13(2), 1-22.

Nash, L., Dobson, D., Crowley, S., \& Nelson, C. (2005). Team Training Manual.

Ohland, M.W., Loughry, M.L., \& Woehr, D.J. (2014). Assessing teamwork skills for assurance of learning using CATME team tools. Journal of Marketing Education, 36(1), 5-19.

Opdecam, E., \& Everaert, P. (2012). Improving Student Satisfaction in a First-Year Undergraduate Accounting Course by Team Learning. Issues in Accounting Education, 27(1), 53-82.

Paguio, R., \& Jackling, B. (2016). Teamwork from accounting graduates: What do employers really expect? Accounting Research Journal, 29(3), 348-366.

Rainsbury, E., Hodges, D., Burchell, N., \& Lay, M. (2001). Ranking Workplace Competencies: Student and Graduate perceptions. Asia Pacific Journal of Higher Education - Research Report, pp. 211.

Reinig, B.A., Horowitc, I., \& Whittenburg, G. (2014). Determinants of Student Attitudes toward Team Exams. Accounting Education, 23(3), 244-257.

Renkema, M., Bondarouk, T., \& Bos-Nehles. (2018). Transformation to self-managing teams: Lessons learned: A look at current trends and data. Strategic HR Review, 17(2), 81-84.

Riley, R.A., Cadotte, E.R., Bonney, L., \& MacGuire, C. (2013). Using a Business Simulation to Enhance Accounting Education. Issues in Accounting Education, 28(4), 801-822.

Schmulian, A., \& Coutzee, S.A. (2019). Students' experience of a team assessment with immediate feedback in a large accounting class. Assessment and Evaluation in Higher Education, 44(4), $516-532$. 
Scholtes, P.R., Joiner, B.L., \& Streibel, B.J. (2018). The Team Handbook (Third Edition). GOAL/QPC Publishing.

Smith, J., Hoffart, G., \& O’Neill, T. (2015). Peer feedback on teamwork behaviors: Reactions and intentions to change. American Society for Engineering Education.

Smith, K.A. (1995). Cooperative Learning: Effective Teamwork for Engineering Classrooms. Conference paper for ASEE Electrical Engineering Conference, pp. 1-11.

Sumaryati, S., Joyoatmojo, S., Wirywan, S.A., \& Suryani, N. (2020). Potential of E-CoPAL Strategy to Improve Analytical Problem Solving and Teamwork Skills in Accounting Education. International Journal of Instruction, 13(2), 721-732.

Swain, M.R., \& Olsen, K.J. (2012). From Student to Accounting Professional: A Longitudinal Study of the Filtering Process. Issues in Accounting Education, 27(1), 17-52.

Swanson, D.J., \& Creed, A.S. (2014). Sharpening the focus of force field analysis. Journal of Change Management, 14(1), 28-47.

Tan, L.M., \& Laswad, F. (2018). Professional skills required of accountants: What do job advertisements tell us? Accounting Education, 27(4), 403-432.

Tannenbaum, S., \& Salas, E. (2021). Teams That Work. Oxford University Press.

Tonge, R., \& Willett, C. (2009). Learning to Think: Using Coursework to Develop Higher-order Academic and Practitioner Skills among Final Year Accounting Students. Accounting Education, $18(2), 207-226$.

Tucker, R., \& Abbasi, N. (2016). Bad attitudes: Why design students dislike teamwork. Journal of Learning Design, 9(1), 1-20.

Tuckman, B.W. (1965). Developmental sequence in small groups. Psychological Bulletin, 63(6), 384.

Tuckman, B.W., \& Jensen, M.A.C. (1977). Stages of group development revisited. Group and Organizational Studies, 2(4), 419-427.

Van der Stede, W.A. (2018). Multitasking Academics. Issues in Accounting Education, 33(3), 85-94.

Volkov, A., \& Volkov, M. (2015). Teamwork benefits in tertiary educations: Student perceptions that lead to best practice assessment design. Education and Training, 57(3), 267-273.

Wells, P., Gerbic, P., Kranenburg, I., \& Bygrave, J. (2009). Professional Skills and Capabilities of Accounting Graduates: The New Zealand Expectation Gap. Accounting Education, 18(4-5), 403420.

White, L. (2018). The Changing Role of Accounting in Enterprise Performance Management. International Federation of Accountants (IFAC).

Willcoxson, L.E. (2016). "It's not fair": Assessing the dynamics and resourcing of teamwork. Journal of Management Education, 30(6), 798-808.

Xyrichis, A., \& Ream, E. (2007). Teamwork: A concept analysis. Journal of Advanced Nursing, 61(2), 232-234.

Zraa, W., Kavanaugh, M., \& Hartle, R.T. (2011). Teaching accounting in the new millennium. Cambridge Business and Economics. CBEC Paper, pp. 1-28.

Zureigat, Q.M. (2015). Accounting Graduates Skills and Employers' Needs: The Saudi Case. Jordan Journal of Business Administration, 11(1), 27-237. 


\section{APPENDIX A: TEAMWORK COURSE SLIDES}

This Appendix is provided separately and can be accessed by emailing the corresponding author at aking@sxu.edu. The appendix is a 134 page PowerPoint document which provides the necessary teaching material to teach the two modules detailed in this document: instructor notes, peer and instructor ratings, and team exercises.

APPENDIX B: PEER EVALUATION FORM

\begin{tabular}{|c|c|c|c|c|c|c|}
\hline \multirow{2}{*}{\multicolumn{2}{|c|}{\begin{tabular}{|l|} 
PEER RATING FORM \\
Reviewer Name:
\end{tabular}}} & \multirow{2}{*}{\multicolumn{5}{|c|}{$\begin{array}{l}\text { Class: } \\
\text { Date: }\end{array}$}} \\
\hline & & & & & & \\
\hline \multirow[b]{2}{*}{$\begin{array}{l}\text { Rating } \\
\text { Category }\end{array}$} & \multirow[b]{2}{*}{ Rating Criteria } & \multicolumn{5}{|c|}{ 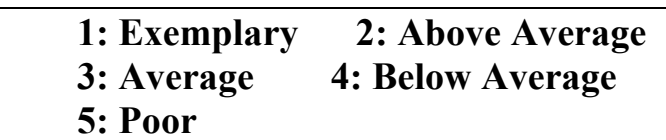 } \\
\hline & & Juan & Maria & Leroy & Robert & Malak \\
\hline $\begin{array}{l}\text { Work } \\
\text { contribution }\end{array}$ & $\begin{array}{l}\text { 1. Completed work assignments } \\
\text { with acceptable quality and on } \\
\text { time }\end{array}$ & & & & & \\
\hline Communication & $\begin{array}{l}\text { 2.Communicated well with all } \\
\text { teammates. Shares information }\end{array}$ & & & & & \\
\hline Helps Others & $\begin{array}{l}\text { 3.Helped other teammates as } \\
\text { required }\end{array}$ & & & & & \\
\hline $\begin{array}{l}\text { Shares } \\
\text { Information }\end{array}$ & $\begin{array}{l}\text { 4.Taught and shared team and } \\
\text { project skills with teammates }\end{array}$ & & & & & \\
\hline Feedback & $\begin{array}{l}\text { 5.Provides appropriate feedback, } \\
\text { and listens well to others }\end{array}$ & & & & & \\
\hline Positive Change & $\begin{array}{l}\text { 6. Promotes and helps develop } \\
\text { positive changes to the team and } \\
\text { the work }\end{array}$ & & & & & \\
\hline Skill sharing & $\begin{array}{l}\text { 7.Helps the team develop skills and } \\
\text { knowledge of team processes }\end{array}$ & & & & & \\
\hline Team process & $\begin{array}{l}\text { 8.Helps to keep the team efficient - } \\
\text { focused and on track }\end{array}$ & & & & & \\
\hline $\begin{array}{l}\text { Summarize } \\
\text { progress }\end{array}$ & $\begin{array}{l}\text { 9.Helps the team summarize } \\
\text { results and develop the final } \\
\text { report }\end{array}$ & & & & & \\
\hline $\begin{array}{l}\text { Report and } \\
\text { Presentation }\end{array}$ & $\begin{array}{l}\text { 10.Helps the team prepare and } \\
\text { present the final report }\end{array}$ & & & & & \\
\hline & Comments: & Total & & & & \\
\hline
\end{tabular}




\begin{tabular}{|c|l|c|}
\hline Aggregate Score & $\begin{array}{c}\text { Qualitative Assessment of Team Member } \\
\text { Contribution }\end{array}$ & $\begin{array}{c}\text { Teamwork Effectiveness } \\
\text { Grade Factor }\end{array}$ \\
\hline $10-17$ & Superior Contributor & $\mathrm{x} 125 \%$ \\
\hline $18-26$ & Above Average Contributor & $\mathrm{x} 110 \%$ \\
\hline $27-34$ & Average Contributor & $\mathrm{x} \mathrm{100 \%}$ \\
\hline $35-42$ & Below Average Contributor & $\mathrm{x} \mathrm{75 \%}$ \\
\hline $42-50$ & Little to no value added & $\mathrm{x} 0 \%$ \\
\hline
\end{tabular}

\section{APPENDIX C: TEAMWORK LEARNING OUTCOMES ASSESSMENT}

Teams Multiple Choice Test - select the correct answer for each question.

1. To set the initial direction for the team, we should use:
a. The Team Roadmap
b. The Team Agenda
c. The Team Charter
d. Instructions from management

2. SMART goals are:
a. Well thought-out and logical
b. Specific, meaningful and action oriented
c. Specific, measurable, and timely
d. Sensible, meaningful, appropriate, reasonable, and targeted

3. The best tool for analyzing a work process is:
a. The process analysis roadmap
b. A process flow chart
c. The process improvement guide sheet
d. A thorough work responsibilities questionnaire

4. Which team role is responsible for resolving conflict between members?
a. Recorder
b. Leader
c. Negotiator
d. Facilitator

5. Which team role is responsible for preparing the agenda for the next meeting?
a. The leader
b. The recorder
c. The planner
d. The facilitator

6. Which role is responsible for issuing minutes from the last meeting, to the team members?
a. The recorder
b. The facilitator
c. The timekeeper
d. The leader 
7. In a team meeting, team members should:

a. Speak only when called upon

b. Make sure they get their points heard

c. Try to impress the leader by dominating the meeting

d. Make jokes whenever possible, to keep the mood light

8. If a team member is being disruptive, the team leader should:

a. Ignore the person, and expect it to get better

b. Confront the person, in the group meeting

c. Ask the facilitator to handle it

d. Talk to the person, outside of the meeting

9. Who is responsible for the team's work quality?
a. The team leader
b. The team quality manager
c. Each team member
d. The mentor for the team

10. PDCA stands for:
a. Prioritize, delegate, control, action
b. Process, define, centralize, activate
c. Plan, do, check, act
d. People, directions, communications, achievement

11. If a team member is not doing their share of the work, the person should be:
a. Criticized in the group meeting
b. Criticized outside of the group meeting
c. Left alone
d. Asked why this is occurring

12. What are appropriate tools for measuring group progress?
a. A survey of the group members
b. Performance statements
c. Charts and graphs
d. Listing of changes made and accomplished

13. Who should get the biggest work load on a project?
a. The person who always does the most work
b. The person who does not do the work - make them work this time
c. Work should be divided equally
d. The person who appears to be the smartest in the group

14. If a team member is being treated disrespectfully, what should you - as a team member - do?

a. Ask the person in the group to stop the bad treatment

b. Ask the person being treated badly to stick up for themselves

c. Ask the leader to address the problem

d. Mock the person who is making the rude comments 
15. What is the best way to keep the team focused?
a. Speak louder when people start to ramble
b. Focus the group back to the meeting plan
c. Have the facilitator correct anyone who is getting out of line
d. As the leader, remind the group that you are in charge, and they need to follow your directions

16. The best feedback is:

a. Collected until you have a lot of it; then summarize it and review it with the person

b. Held back so that you do not cause conflict with a person

c. Timely - given as close to the event as possible

d. Compared with comments that you get from others, so that you give the person a complete picture

17. Which role is generally not concerned with developing their own skills as part of the team?
a. The recorder
b. The mentor
c. The sponsor
d. The facilitator

18. How should team performance be measured and graded?
a. All team members should receive the same grade
b. Grades should vary based on contribution, as rated by the team
c. Grades should vary based on meeting between the instructor and the team leader
d. The instructor should award grades based on their opinion

19. Team learning and skills should be:
a. Summarized on paper
b. Maintained in a journal or an ePortfolio
c. Kept in an organized file folder with pictures
d. Remembered; I will recall what I can when I need them

20. The process which a team follows is:
a. Decided upon by the team leader
b. Defined in a manner which we should follow
c. Fairly flexible - we have group meetings all the time
d. Defined by the team Mentor

21. Which statement is not true:
a. My future employer will teach me teamwork, if that's what they want me to have
b. Employers expect me to start work with some decent teamwork skills
c. Working as a good team member will be expected in most workplaces
d. Good team skills and interpersonal skills will likely benefit me in my career 